\title{
The Strategy to Increase the Regional Revenue (PAD) of the Government of Central Kalimantan through the Governor Regulation No. 16/2018
}

\author{
Suprayitno ${ }^{1}$ \\ Riamona Sadelman Tulis ${ }^{2}$ \\ Ira Zuraida ${ }^{3}$
}

\begin{abstract}
This article aimed to analyze and identify the strategies of Central Kalimantan Provincial Government as an effort to increase Regional revenue (Pendapatan Asli Daerah - PAD) through third-party grants or donations. One of the efforts made by the Central Kalimantan Provincial Government in increasing regional revenue $(P A D)$ is through the issuance of Governor Regulation No. 16/2018 on Guidelines for the Acceptance and Management of Grants or Donations from Third Parties to the Central Kalimantan Provincial Government. The data showed that the governor's regulation had shown positive results relating to the efforts to increase the Regional revenue in Central Kalimantan Province. Local Revenue Offices of Central Kalimantan as the leading sector to implement the regulation has made several strategic efforts including sharing/spreading the information to $3 \mathrm{P}$ i.e., investors, monitoring and controlling. The purposes of the governor's regulation No. 16/2018 to provide legal protection to guarantee the participation of third parties in Central Kalimantan development, provide legal certainty in the management and acceptance of third-party grants or donations, and create an orderly administration, transparency and accountability in acceptance the grants or third-party donations to the government of Central Kalimantan Province. The collaboration cooperation between Central Kalimantan Provincial Government and the private sector to increase Regional revenue (PAD) needs to have support from all parties.
\end{abstract}

\section{Keywords:}

strategy; regional revenue (PAD); grants; third-party donations

\section{Introduction}

Process in government administration in the region consists of many activities which have the purpose of developing the region and guaranteeing the prosperity for its society. Law No. 23/2014 stated that regional government is the government administration organizer by the regional government and regional house of representatives according to autonomous principle and assistance task with the autonomous principle in the system and principle of Indonesian Republic as mentioned in UUD 1945 (constitution).

\footnotetext{
${ }^{1}$ Department of Public Administration, Social and Political Science of Palangka Raya University Email: suprayitno@fisip.upr.ac.id

${ }^{2}$ Department of Public Administration, Social and Political Science of Palangka Raya University Email: monafisip@gmail.com

${ }^{3}$ Department of Public Administration, Social and Political Science of Palangka Raya University Email: ira_pensa@yahoo.com
} 
Since the decentralization and regional autonomy system began in Indonesia, the regional government has the authority to regulate its own region. Law No. 23/2014 Article 1 No. 6 provides the definition of regional autonomy, which the Regional Autonomy is the right, authority, and obligation of autonomous regions to regulate and manage the Government Affairs and the interests of the local community in the system of the Republic of Indonesia. The manifestation of regional government management looks from various sides, both macro and micro. With the greater authority in managing the region itself, it is hoped that the area can be built, maintained and organized by the regional government optimally. Surely, even the central government has given regional authority to regulate selfgovernment freely, but there must also conduct the principle of responsibility. In optimizing the decentralization, the regions need to make regional regulation.

In Law No. 23/2014 article 31 stated that regional regulation has the objectives: a) Implementing the effectiveness of the regional government implementation, b) Accelerating the improvement of community welfare, c) Accelerating the quality of public services, d) Improve the quality of governance, e) Improve national and regional competitiveness, and $f$ ) Maintain the uniqueness of local customs, traditions, and culture. According to Mardiasmo (2004), Basic Principles of Regional asset management includes three main things, namely: (1) The existence of appropriate planning, (2) Implementation/Utilization efficiently and effectively, and (3) monitoring.

One of the functions of the regional government as the executive in the region is managing the financial policies. The vital aspect on the financial management usually asks on how a region can be balanced and professional on the financial management, both in terms of managing the Regional revenue and also managed in regional expenditures planned in the APBD (Budget). Ideally, revenue and expenditure in the region must balance, aiming the government organization and developmental programs can run continuously along with the set of objectives.

The regional head has an important role to bring the regional government management in line with the vision and mission as the target to achieve. One of the missions of Governors and Deputy Governors of Central Kalimantan, H. Sugianto Sabran and Habib Said Ismail as outlined in the Central Kalimantan Regional Medium-Term Development Plan (RPJMD) for 2016-2021 is; going to Central Kalimantan BERKAH (Dignified, Elegant, Religious, Strong, trustworthy, and harmonious). The missions of the Province of Central Kalimantan in 2016 - 2021 are as follows:

a. Strengthening the spatial plan of the province;

b. Acceleration infrastructure development;

c. Management the resources of water, coastal and beach;

d. Inflation control, economic growth, poverty alleviation;

e. Increased economic activity in the middle of the community;

f. Strengthening the professional, fair and anti-corruption of regional government governance;

g. Education, health and social culture;

h. Environmental and natural resource management;

i. Regional revenue management;

The real efforts currently being carried out by the Central Kalimantan provincial government to implement the Kalteng Berkah of vision and mission are by optimizing the Regional regional revenue $(P A D)$. This is because the regional revenue is an important component in the successful implementation of development programs. Therefore, the Provincial Government of Central Kalimantan through the Regional revenueOffice implements 
various strategies and innovations in order the regional Regional revenue increase and to minimize the dependence of regional governments to the central government. Anggara (2016) stated that Regional revenue is an income from regional's efforts through intensification and extensification of sources. Intensification is carried out on common sources of the region by means of adjustments the rates, service system improvements, control of objects and fines. Extensification is carried out to increase the common source of income by adding new sources that are permitted by legislation.

One of the strategies carried out by the Central Kalimantan provincial government is by issuing the Governor Regulation No. 16/2018 on Guidelines for the Acceptance and Management of Grants or Donations from Third Parties to the Central Kalimantan Provincial Government. The purposes of the Governor Regulation No.16/2018 on Guidelines for the Acceptance and Management of Grants or Donations from Third Parties to the Central Kalimantan Provincial Government are as follows:

a. As a guideline for regional governments in carrying out the process of grants or donations from third parties.

b. As a guideline for the Central Kalimantan Provincial Government apparatus and third parties in supporting and actively participating in the construction and provision of infrastructure for the benefit of the people of Central Kalimantan province.

c. As a guideline for third parties in conducting supervision and transparency in the process of grants or donations from third parties to the Government of Central Kalimantan Province.

With the Governor Regulation No. $16 / 2018$, hopefully, it is able to support and facilitate the development and implementation of regional government through funding sources that sourced from participation and role of third parties in the form of grants or donations. The issued the Governor Regulation No. 16/2018 has gone through a quite long discussion in the Province of Central Kalimantan. Since 2016, at the beginning of the leadership of Governor Sugianto Sabran - Habib Said Ismail, the regulation has been initiated but due to the interest, in 2018, officially implemented in Central Kalimantan.

Today, the legal products on Grants and third-party Donations from the private sector in Central Kalimantan are the only legal products in Indonesia. Moreover, it attracts the attention of several provinces in Indonesia so that they are interested in studying this regulation to Central Kalimantan. During the time, the Governor Regulation No. 16/2018 has been declared as clear and clean to implement in Central Kalimantan Province after going through a number of lengthy feasibility and preparation processes, as well as consultations to several parties including the Saber Pungli Team of Police of Central Kalimantan Regional, Central Kalimantan High Prosecutor's Office and also the Commission Eradication Commission (KPK) by the Central Kalimantan Provincial Government.

One of the reasons of the issued of Governor Regulation No. 16/2018 was due to the concern of the Central Kalimantan provincial government regarding many business sectors of $3 \mathrm{P}$ (mining, plantation and forestry) and other businesses that invested in Central Kalimantan but they had not contributed significantly to the development in Central Kalimantan. In addition, the dependence of the Central Kalimantan Provincial Government on funding from the Central Government is still high, so there is a need for innovation in finding funding to sustain the development of Central Kalimantan Province to create an independent regional government. With the Governor Regulation No. 16/2018, hopefully, there will be transparency, orderly administration, and 
accountability on the acceptance of grants and third-party donations. As an area has abundant wealth in $3 \mathrm{P}$ (plantation, mining, and forestry) in Central Kalimantan, then the governor's regulation should present in order to increase the revenue, especially grants and contributions from third parties from the plantation, mining and forestry sectors that invest in Central Kalimantan.

The abundant wealth of natural resources in Central Kalimantan must use as well as possible for the development and welfare of the people in Central Kalimantan. This becomes the opportunity for the Central Kalimantan provincial government to freely regulate anyone; anyone who invests in Central Kalimantan. Besides in the aim to make the profit, but also it has the social responsibility and commitment to participate in developing the Central Kalimantan. With the commitment of the business world, the local government and stakeholders have a sense of belonging to develop. So, the progress of the development in Central Kalimantan can be carried out together and more maximal to implement the Central Kalimantan Berkah (Dignified, Elegant, Religious, Power, Trustworthy, and harmonious).

\section{Literature Review}

Public policy is a series of interconnected choices made by institutions or government officials in the fields that involve government tasks, such as defense security, energy, health, education, community welfare, crime, urban and others (Pasolong, 2008).

Public policy is a strategic use of existing resources to solve public or government problems. Public policy is a form of continuous investment by the government for the benefit of people who are powerless in society so that they can live and participate in government (Pasolong, 2008).

Chaizi Nasucha in Pasolong (2008) stated that public policy is the authority of the government in making a policy to use in the regulations. The policy aims to absorb the social dynamics in the community and use as a reference for policy formulation to create harmonious social relations. According to Dye in Pasolong (2008) stated that public policy is "whatever the government chooses to do or not do." Dye stated that if the government chooses to do something, then there must be an objective. Moreover, public policy covers all government actions; so, it is not merely a statement of the wishes come from the government or government officials.

In general, the policy divides into four: (1) Regulatory; regulating people's behavior, (2) Redistributive; redistributing the wealth/ taking the wealth from the rich and distributing to the poor, (3) Distributive; distributing or providing equal access to certain resources and (4), Constituent; has to purpose to protect the State.

Public policy has an important role in managing the public order both at the center and in the regions. The types of public policies according to Law No. 12/2011 on the establishment of Regulations Article 7 explained the types and hierarchy of the Laws and Regulations as follows:

1. The UUD 1945 (1945 Constitution of the Republic of Indonesia).

The 1945 Constitution of the Republic of Indonesia, or abbreviated as the 1945 Constitution or the 1945 Constitution (UUD 1945 or UUD ‘45), is a basic law, and the highest state constitution in the Republic of Indonesia. The 1945 Constitution is the written Law of the Republic of Indonesia and functions as the highest legal source in Indonesia. The 1945 Constitution has undergone four times of amendment as part of the improvement. Today, the 1945 Constitution has 16 chapters, 37 articles, 194 verses, 3 chapters for the Transitional Rules, and 2 chapters for Additional Rules. 
2. Decree of the People's Consultative Assembly

The decree of the People's Consultative Assembly, or abbreviated as the MPR Decree or the TAP MPR, is a form of the decision of the People's Consultative Assembly which contains stipulating things (beschikking).

In the period before the Amendment of the 1945 Constitution, the Decree of MPR was a Legislation which was hierarchically under the 1945 Constitution and above the Law. The decree of MPR has been abolished at the beginning of the reform as a source of law. In the early days of reform, the decree of MPR has no longer included on the order of the hierarchy of law in Indonesia. However, in 2011, based on Law No. 12/2011, the decree of MPR became a Legislation which was hierarchically under the 1945 Constitution.

3. The Laws/government regulation lieu of the law

The Law is a regulation to implement the 1945 Constitution. The institution authorized to make the laws is the DPR (House of Representative) with the President. The criteria for a problem/matter/case to be regulated through the Law are:

a. The law is made by order the provisions of the 1945 Constitution.

b. The law is made by order the previous law

c. The law is made to revoke, change and add the laws

d. The law is made on human rights

e. The law is made on obligation or interest of people

The procedures in making the laws are:

a. DPR holds power to make the laws.

b. Each draft of the law is discussed by the DPR and the President to obtain agreement.

c. Draft of Law (RUU) may make by the DPR, President, or DPD.

The Government Regulation in lieu of the law (Perpu) issued by the President without obtaining DPR approval. Perpu is made in an "emergency" state or urgent because problems must have immediately solved. After the enactment, the Perpu must submit to the DPR for approval.

\section{Government Regulation}

A Government Regulation is issued to implement a law. Government regulations are made to implement the law. The criteria in issuing the Government Regulations are:

a. Government regulations might not issue without the existence of the head law. Every issuing the Government Regulation must base on the existing laws.

a. Government regulations might not include criminal sanctions if the head law does not state criminal sanctions. The regulated in a Government Regulation must be the details or further elaboration of the head law. So, when the law has not regulated the issue of criminal sanctions, then the Government Regulation may not contain criminal sanctions.

b. Government regulations might not expand or reduce the provisions of the head law. Content or material of Government Regulations only regulates in more detail on has been regulated in the head law.

c. Government regulations might issue even though the law does not explicitly state, but the Government Regulation aims to implement the Law. The Government Regulations issued to implement the established laws, even though the law does not explicitly require the establishment of a Government Regulation.

\section{Presidential Decree}

The Presidential Regulation or presidential decree is a regulation made by the President in organizing the state government as an attribute of Article 4 paragraph (1) of the 1945 Constitution of the Republic of Indonesia. The Presidential Regulation is issued to further 
regulate the orders of Laws or Government Regulations either expressly or not explicitly ordered the establishment.

\section{Provincial Regulation}

Provincial Regulation is a regulation issued by the Regional House of Representative with the approval of the Governor. Provincial Regulations issued to implement higher legislation and functions to carry out the regional needs. Therefore, in making the Regional Regulations must adapt to regional needs. The material for Regional Regulation is all content material in the framework of implementing the regional autonomy and coadministration tasks.

\section{Regency/City Regional Regulations}

Regency/City Regional Regulation is a regulation issued by the Regency/City Regional House of Representative with the approval of the Regent/Mayor.

Governor Regulation No. 16/2018 is one of the products of regional policy at level 1 , in this case, is the Regional Government of Central Kalimantan Province. The governor's regulation is part of the authority of the governor of Central Kalimantan in order to provide legal certainty and also guidelines for the business sector, especially sector $3 \mathrm{P}$ (mining, plantation, and forestry) in providing grants or third-party donations. An innovative strategy is needed aiming the regulation can implement properly in Central Kalimantan.

Daft (2002), the definition of Strategy is a plan of action that outlines the allocation of resources and activities to respond to the environment and help to achieve the goals or objectives. Meanwhile, according to strategy defined as a process of determining the way the top leader focuses on the long-term goals of the organization, accompanied by the preparation of a way or effort to achieve the goal.

The term strategy comes from Greek "strategeia" (one hundred=military; and ag=lead) which means art or science to become a general. Meanwhile, according to Riadi the strategy is the whole step (policies) with definite calculations to achieve a goal or to overcome a problem (Reliant, 2017).

Definition of Strategy is a plan of action that outlines the allocation of resources and activities to respond to the environment and help to achieve the goals or objectives (Daft, 2002). Meanwhile, according to Umar (2001) strategy defined as a process of determining the way the top leader focuses on the long-term goals of the organization, accompanied by the preparation of a way or effort to achieve the goal.

Based on the previous definitions, concluded that the strategy is a plan or step made by the decision maker to achieve the desired goal or solve a problem with formulas that apply short-term or long-term.

The concept of the strategy as follows (Reliant, 2017) :

\section{Strategy as a plan}

The strategy is a plan, in line with the strategic plan inserted by Glueck, where stated that "strategy is an integrated, comprehensive, and integrity plan which is designed to ensure the goal able to achieve."

\section{Strategy as a pattern}

The strategy is a pattern that shows a series of activities conducted by management to reach the goal. Solihin (2012) divided strategy as a pattern into; intended strategy, deliberate strategy, unrealized strategy, emerging strategy, and realized strategy. Based on the observation, Mintzberg found phenomena that intended strategy by a company through a process, converted into deliberate strategy, often change into unrealized strategy, due to the environmental company (Solihin, 2012). In contrast, the strategy also may appear as emerging strategy if the strategy implemented becomes realized strategy. 


\section{Strategy as a perspectif}

This strategy shows the perspective of strategist in view the world. The strategy is alive though within strategist. Like an ideology or culture, it then tries to convert into values in an organization.

The strategy used by the Regional Revenue Office as a way to increase regional revenue (PAD) is the extent to which the Governor's Regulation No. 16/2018 might carry out properly in Central Kalimantan. By the good planning strategy, hopefully, the regulation might run well without any significant obstacles in its implementation. Maximum planning is important as an important part of the successful implementation of the regulation. Discussing the plan, before it truly became a legal regulation, the Central Kalimantan provincial government had consulted the content on the regulation to the eradication of illegal collection section of Central Kalimantan regional police, the Attorney General's Office and the Corruption Eradication Commission (KPK).

In its implementation, the strategy used to increase the local Regional revenue also has a pattern and a series of activities to achieve the goals. One of the activities carried out by the Regional Revenue Office is; before implementing the governor's regulation, the Regional Revenue Office disseminate information of the regulation to the people of Central Kalimantan and the companies as the target and subject of grants and third-party donations. In its perspective, the content of the Governor's Regulation No. $16 / 2018$ also adjusts the conditions of the Central Kalimantan region. In this case, the governor issued the governor's regulation because Central Kalimantan has a lot of resources from Sector $3 \mathrm{P}$ but has not provided optimal impact.

Beside the previous concept, Subkhi and Jauhar (2013) stated another strategy theory in an organization. According to Chandler, concluded that the changing of strategy caused the international strategy. He stated that "structure follow the strategy". The strategy of organization is influenced by opportunities and threats from external factors; purposes, values and trust from members, as well as the strength and the weakness. On occasion, this strategy will influence the structure of the organization. The detail is as follow:

1. Strategy determines the organizational activity as the basis for organizational design.

2. Strategy influence the selection of technology and people in implementing the activities, and it then influence the appropriate structure.

3. Strategy determines the specific environment where the organization will have a potency to influence the structure

One indicator of the success or failure, the policy strategy carried out by the Central Kalimantan Provincial Government on the implementation of the Governor Regulation No. 16/2018 is on how the regulation will be well implemented in the future. Implementation according to Daniel Mazmanian and Paul Sabatier in the book "Implementation and Public Policy" defines the implementation of policy as the implementation of basic policy decisions, usually in a law, but may also be in orders, important decisions executive or judicial body decisions (Agustino, 2014). Typically, the decision identifies the problems, explicitly states the goals or objectives, and various ways to structure or regulate the implementation process. The model of public policy implementation proposed by George C. Edward III in Indiahono (2009) shows four variables that play an important role in reaching the successful implementation. The four variables are communication, resources, disposition, and bureaucratic structure.

\section{a. Communication}

Communication is the process of delivering information from the communicator to the communicant, which is the recipient of the information. Meanwhile, policy 
communication means the process of delivering policy information from policymakers to policy implementors (Widodo, 2011). Widodo then added that information needs to be conveyed to policy target, so that policy target can understand the content, purpose, direction, target group of policies and they can prepare any matters relating to the implementation of policies. It aims the process of policy implementation can run effectively and in line with the objectives of the policy. Communication in the implementation of the policy includes several important dimensions; information transformation (transmission), information clarity and information consistency. The transformation dimension requires that information not only deliver to policy implementors but also to target groups and related parties. The dimension of clarity requires that information is clear and easy to understand, also to avoid misinterpretations of policy implementers, target groups and parties involved in policy implementation. And the consistency dimension requires that the information must be consistent aiming the information does not make confusion for policy implementors, target groups or related parties.

\section{b. Resources}

The resource has an important role in the implementation of policy. Edward III in Widodo (2011) stated that anyhow the clarity and consistent the term and condition, as well as the accurate in conveying of the term and condition itself, if the policy implementers have not sufficient resource to implement the policy effectively, so the implementation will not be effective. Resource, in this case, relates to anything to support the success of policy implementation. The resources are human resource, budget, facility, information, and authority.

\section{c. Disposition \\ Disposition means the tendency of attitude or characteristic of policy implementors. The}

attitude or characteristic of policy implementors has an important role in the implementation of policy in line with goal or target. The important characters of policy implementers are honesty and high commitment. Honesty attitude makes the policy implementers staying at the program. Meanwhile, high commitment will make them always be enthusiastic about performing the job, authority, function, and responsibility in line with the applicable regulation. The action of policy implementors will very influence the implementation of policy. If the policy implementers have good action, then they will run well the policy in line with the guideline of policymakers. In contrast, if they have bad action, surely, the implementation will not run well implemented.

\section{d. Bureaucratic Structure}

Bureaucratic Structure has significant influence toward the implementation of policy. The aspects of bureaucratic structure include two things; mechanism and the bureaucratic structure itself. The first aspect is the mechanism. Standard operation procedure (SOP) is made in the implementation of policy. Standard operation procedure (SOP) is made as the guideline for implementor aiming their action always is in line with the purpose and target of policy. The second aspect is the bureaucratic structure. The long and fragmented of Bureaucratic Structure will tend to weaken the monitoring and make the Bureaucratic become complex and complicated and make the activity of organization will not be flexible.

Osborne and Peter Plastrik in "Rewriting Government's DNA: Strategies for Building a Better Public Sector," in The New Democrat. Washington, DC: Democratic Leadership Council, March/April 1997, stated that institutions must have several normative models so that activities can maximize the efficiency and effectiveness. The model of the organization or institution must be supported by opinions and other supporting models. 


\section{Discussion}

The differences the development among regions led to a gap in prosperity and progress among regions, especially between Java and outside Java, between the Western Region of Indonesia (KBI) and Eastern Region of Indonesia (Kuncoro, 2018). Therefore, the emergence of decentralization and regional autonomy is one of the solutions to equity and acceleration of development in Indonesia.

The factor in supporting the decentralization and regional autonomy is that the aim to encourage the acceleration of community welfare and acceleration development in all fields through improving services, empowerment and community participation in accordance with the potential and management capabilities of available resources in governance and management in the region. One of the regions in Indonesia which are currently stretching its development began to accelerate is Central Kalimantan Province. As Provinces that build infrastructure, facilities, public infrastructure, and other needs to complement the community welfare, this is certainly not an easy matter. Therefore, the Central Kalimantan Provincial Government tries to innovate to increase revenue as one of the basic needs for the success of development programs. Regional revenue, not only in Central Kalimantan but also either in the Province or in other regencies/cities has an important role in the development programs both physically and non-physically. Every year, each region has a target of regional revenues $(P A D)$ within a certain period of time as a barometer of future development.

The Central Kalimantan Province in its developmental program has a high dependency on the Central Government through Transfer/ Balance Funds that exceed the regional revenue $(P A D)$. Regional revenue in Central Kalimantan is only able to contribute one-third of the funding received by this province from all of the revenue targets in 2018. This fact is certainly
Table 1.

The target of revenue in Central Kalimantan Provincial Government in 2018

\begin{tabular}{|c|c|c|}
\hline No & Component & Target of Revenue \\
\hline 1 & $\begin{array}{l}\text { Local Regional revenue } \\
(P A D)\end{array}$ & IDR $1,400,710,256,900$ \\
\hline 2 & Transfer funds/ Balance & IDR $3,010,373,600,000$ \\
\hline \multirow[t]{3}{*}{3} & $\begin{array}{l}\text { Other Legitimate } \\
\text { Regional revenues }\end{array}$ & $1,024,800,000$ \\
\hline & Total & IDR $4,412,108,656,900$ \\
\hline & $\begin{array}{l}\text { Source of Regulations: } \\
\text { 1. Central Kalimantan } \\
\text { Provincial Regulation } \\
\text { number } 6 \text { of } 2017 \\
\text { on Revenue and } \\
\text { Expenditure } \\
\text { Budget for Central } \\
\text { Kalimantan Fiscal } \\
\text { Year of } 2018 \\
\text { 2. Regulation of } \\
\text { Governor's of } \\
\text { Central Kalimantan } \\
\text { Number } 51 \text { of } 2017 \\
\text { on description } \\
\text { the Revenue and } \\
\text { Expenditure } \\
\text { Budget for Central } \\
\text { Kalimantan Fiscal } \\
\text { Year of } 2018 .\end{array}$ & \\
\hline
\end{tabular}

not ideal in development. Aiming to solve the problem, the Central Kalimantan Regional Government needs innovation to increase the Regional Regional revenue through other policies. With the high dependence on transfer funds/balances, ideally, creating an independent region will be difficult.

In Article 295 paragraph 1 of Law No. 23/2014 on Regional Government stated that other legitimate regional Regional revenues are all Regional revenues other than Regional revenue and Transfer Revenues which include grants, emergency funds, and other revenue in line with regulatory provisions legislation. With the issuing the Governor Regulation No. $16 / 2018$ as a guideline for implementing the receipt and management of grants or donations from Third Parties to the Government of Central Kalimantan Province, so it is clear that the matter regulated in Governor No. 16/2018 is Regional revenue as stated in Law No. 23/2014. 
Surely, it hopefully the governor's regulation might have a significant impact in increasing the independence of Central Kalimantan in developing plans for sustainable development programs in the future.

The management of regional revenue $(P A D)$ needs innovation and commitment of all party to avoid the leaking of revenue. According to Sobandi (2005), the strategies in the context of empowering Regional revenue are: (1) Data consolidation strategy (DCS), if the data of potential of revenue sources is certainly unknown; (2) Indirect Empowerment Strategy (IES), if macroeconomic indicators (such as PDRB) have a big influence on the revenue; (3) Non-Tariff Empowerment Strategy (NES), if the rate does not have a big influence on the revenue; (4) Tariff Empowerment Strategy (TES), if the rate has a big influence on the revenue; (5) TargetPotential Synchronization Strategy (TPSS), if there is an inconsistency between the target and the real potential; (6) Intensification Strategy (IS), if the efforts of revenue is low due to weaknesses in various factors that directly determine the amount of revenue, such as system, institution, and Human Resource; (7) Extensification Strategy (ES), if the effort of revenue is low due to the lack of breadth scope of the subject of revenue or the foundation of revenue.

Leading sector the enactment of Governor Regulation No. 16/2018 is the Regional revenue Office of Central Kalimantan Province which is currently headed by H. Kaspinor, SE. M.Sc. as the head of the Office. In line with the vision of the Revenue Office which is to realize an increase in regional Regional revenue oriented to quality public services. And the missions are to explore and develop the sources of Regional revenue, improve the quality of public services, establish networking and strategic coordination to increase Regional revenue (PAD) and improve the performance of human resources and organizations. With the vision and mission, increasing in the PAD sector is a goal of the Central Kalimantan Provincial Revenue Office.
The readiness of the Government of Kalimantan Province in the Implementation of Governor Regulation No. 16/2018 that is as an indicator of these variables are communication, resources, disposition, and bureaucratic structure.

\section{a. Communication.}

The promotion is one of the active communication media of the Kalimantan provincial government to inform the Governor Regulation No. 16/2018 to all people in Kalimantan. The promotion carried out by the Central Kalimantan provincial government was Seminar and Workshop. The Central Kalimantan Provincial Government through the Central Kalimantan Regional Revenue Office (Bapenda) ever promoted the governor's regulation by inviting businesses, regents/ mayors in Central Kalimantan, provincial/ district/city-level heads of Office in Central Kalimantan, academics, traditional leaders, community leaders, representatives of youth and community organizations on July 18, 2018 at the Eka Hapakat Hall, Central Kalimantan Governor's Office, which was officially opened by the Central Kalimantan Governor, H. Sugianto Sabran. In the agenda, the business community welcomed the Regulation Governor No. 16/2018.

Through active communication carried out by the provincial government, hopefully, all parties can mutually support the Implementation of this Governor Regulation aiming can implement properly. Not only through workshops, but the Provincial Government through the related offices also intensively published the governor's regulations through the online broadcasting in Videotron in the front of the Istana (palace) Isen Mulang, and promote the information directly to the field. In an effort to provide transparency to grant providers and also the public, the grantor or third-party donations are published on the website of Central 
Kalimantan provincial government. The Central Kalimantan Provincial Government through the Regional Revenue Office (Bapenda) has actively and passively made an innovative breakthrough aiming the governor's regulation can well implement in the future. The Central Kalimantan Provincial Government through the Regional revenue Office has routinely gone to the field in supervising and promoting the Governor No. 16/2018.

\section{b. Resources.}

An important factor that is inseparable in the success of the public policy is to prepare professional and complete resources such as human resources, facilities, and infrastructure. Currently, the human resources prepared by the Central Kalimantan Provincial Government as the leading sector are the Regional Revenue Office (Bapenda) of Central Kalimantan Province and the Office currently has around 300 civil servants who are both civil servants and have
14 UPTDs (integrated regional service units) in 13 regencies and 1 city in Central Kalimantan province. Besides, other supporting facilities and infrastructure have completed, such mobile cars and also the UPTD office as supporting facilities in order the strategy to increase the regional revenue $(P A D)$ able to achieve and realized properly. The Central Kalimantan Provincial Revenue Office as the leading sector has now been supported by the UPTD (regional integrated service units) in 1 City and 13 regencies in Central Kalimantan. With 14 UPTD in Central Kalimantan, hopefully, there will be a significant increase in regional revenue $(P A D)$ especially in the field of grants and third-party donations through the Governor's Regulation No.16/2018.

The large of the geographical condition of Central Kalimantan and the far distance between one region and another region are certainly, one of the crucial problems for the effectiveness of the governor's regulation. Also,

Figure 1.

Map of the 14 UPTD in Central Kalimantan

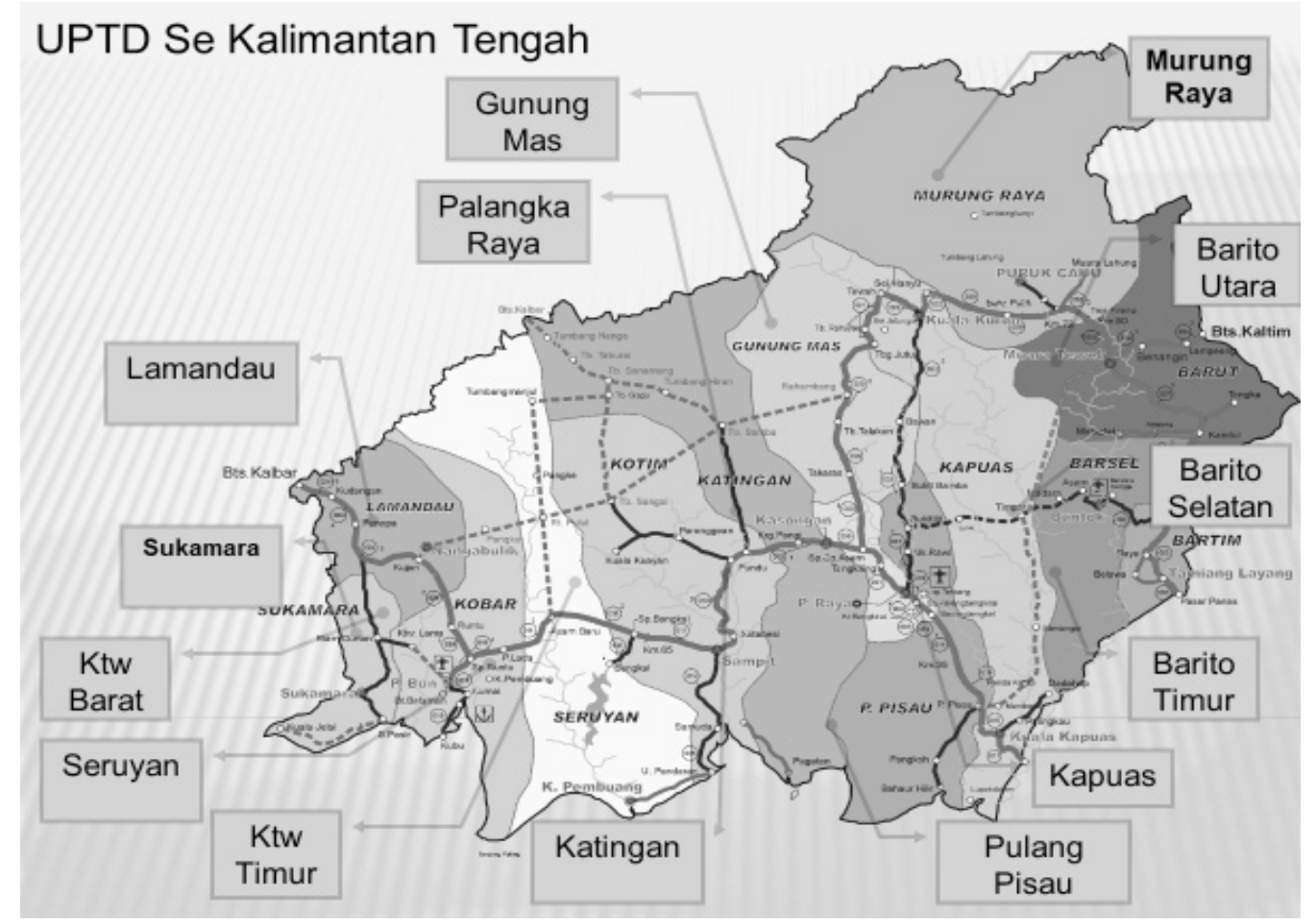

Source: Regional Revenue Office Central Kalimantan Province Year 2018 
the lack of infrastructure is also a problem in Central Kalimantan. Therefore, with the 14 UPTDs in 13 Regencies and 1 City, certainly facilitate the regional government in terms of implementing the Governor Regulation No.16/2018 in the future. Thus because most sector of $3 \mathrm{P}$ businesses (mining, plantation, and forestry) in Central Kalimantan, investors invest in the Regency.

\section{c. Disposition.}

As theleading sectorin the implementation of the policy, the State Civil Servant $(A S N)$ in the Central Kalimantan Provincial Revenue Office must have an attitude of service and care to its integrity in providing maximum service, especially on grants and donations from third parties. Collaboration between the government and the business world certainly must be built on the basis of trust and responsibility because this involves commitments from various parties. The state civil apparatus that has a good disposition will certainly also be directly proportional to be able to carry out the policy. Currently, ASN in the Central Kalimantan provincial government has carried out its main duties and functions, especially on the Governor Regulation No. 16/2018. It shows that they have successfully implemented promoted through a workshop on governor regulation to communities in Central Kalimantan, especially to the business sector of 3 P. Besides conducting promoting in the workshop, surely, they also carried out other work to support the running of government processes in the regional government.

\section{d. Bureaucratic Structure}

As a concrete step to support the implementation of Governor Regulation No. 16/ 2018 in the field for particularly, the Provincial Government of Central Kalimantan through the Provincial Revenue Office has developed a mechanism on the organizational structures of service to the third-party contributions, including the Central Kalimantan Regional Financial Office, Central Kalimantan Revenue Office, and Public Order Enforcers (Satuan Polisi Pamong Praja). For example, the content of implementation in the field is the responsibility of the regional revenue Office, while the content of receiving third party grants/donations is the responsibility of the regional financial Office. With the Bureaucratic Structure, hopefully, the Governor's Regulation No. 16/ 2018 can implement properly and transparently.

The complex problem of public policy requires cooperation from many parties so that public policy can well implement. When the bureaucracy structure of the policy is not conducive to the implementation of a policy, this condition will impact the ineffectiveness and obstruct the implementation of the policy. Meanwhile, the Governor's Regulation No. $16 / 2018$ has a good goal in order to increase the regional Regional revenue maximally. Therefore, it is a bad news if the policy does not run according to the designed plan. By a Standard Operational Procedure (SOP) in each office, it should increase the trust and convenience of the business world that are willing to give a third grant or contribution in the form of money, goods or services.

Collaboration between the Central Kalimantan Provincial Government and the private sector in increasing the regional revenue $(P A D)$ needs the support of all parties. Central Kalimantan, which is rich in natural resources, there must be particular attention to this matter aiming the wealth can use as well as possible in improving the welfare of the people in Central Kalimantan. Before the enactment the Regulation No. 16/2018, the private sector when distributing grants and third-party donations both to the community and the Regional Government (Government of city/Regency) was less orderly in the administration, then hopefully the implementation of the Regulation would create orderly, transparency and accountability administration of receiving 
Table 3.

The elaboration of 4 variables

\begin{tabular}{|c|c|c|c|}
\hline Variable & The current Condition & Problem Identification & Ideal Condition \\
\hline Communication & $\begin{array}{l}\text { The Provincial Government } \\
\text { through the Office of Regional } \\
\text { Revenue of Central Kalimantan } \\
\text { Province has informed the } \\
\text { Governor's Regulation no. } 16 \text { of } \\
2018 \text {. } \\
\text { But, so far, the information } \\
\text { dissemination of the regulation } \\
\text { is still limited through videotron } \\
\text { and the workshop. } \\
\text { The employees of Regional } \\
\text { Revenue Office have } \\
\text { disseminated the information to } \\
\text { regions, but not all area knows } \\
\text { the information, such areas of } \\
\text { Sector } 3 \text { P (mining, plantation } \\
\text { and forestry), the most located } \\
\text { in the regency toward the } \\
\text { governor's regulation number } \\
16 \text { of } 2018 \text {. This is because the } \\
\text { location of companies is far from } \\
\text { the capital city of the regency. }\end{array}$ & $\begin{array}{l}\text { The governor's Regulation is } \\
\text { relatively new and is not fully } \\
\text { known by the public widely in } \\
\text { Central Kalimantan province. } \\
\text { It needs more active and } \\
\text { massive communication related } \\
\text { the enactment of governor's } \\
\text { regulation number } 18 \text { of } 2018 \text { in } \\
\text { Central Kalimantan province. } \\
\text { The information dissemination } \\
\text { is not only through Videotron } \\
\text { and formal ways. } \\
\text { Massive information } \\
\text { dissemination might be } \\
\text { through radio, advertisements } \\
\text { on local TV, printed media } \\
\text { and employees of Regional } \\
\text { Revenue Office including in the } \\
\text { regional UPTD, can be perform } \\
\text { door to door dissemination of } \\
\text { information to companies that } \\
\text { have potential income from } \\
\text { third-party grants/donations. } \\
\text { Because the geographical area } \\
\text { is quite diverse. So, there must } \\
\text { be innovation related to the } \\
\text { dissemination of information } \\
\text { on the regulation aiming the } \\
\text { regulation can be known to all } \\
\text { community. }\end{array}$ & $\begin{array}{l}\text { All communities in } \\
\text { Central Kalimantan, } \\
\text { especially company, in } \\
\text { this case, are companies } \\
\text { in the sector of } 3 \mathrm{P} \\
\text { (mining, plantation, and } \\
\text { forestry), should know } \\
\text { the enactment of Central } \\
\text { Kalimantan Governor's } \\
\text { Regulation No. 16/2018. } \\
\text { With the active } \\
\text { communication from all } \\
\text { parties, sector } 3 \text { P as one } \\
\text { of the local Regionals } \\
\text { revenue can give a real } \\
\text { contribution through } \\
\text { third-party grants / } \\
\text { donations according to } \\
\text { the rules in governor's } \\
\text { regulation No. } 16 \text { of } 2018 \text {. }\end{array}$ \\
\hline Resources & $\begin{array}{l}\text { Currently, the Regional Revenue } \\
\text { Office of the Central Kalimantan } \\
\text { has around } 300 \text { employees, } \\
\text { both civil servants and contract } \\
\text { workers, as resources in the } \\
\text { Regional Revenue Office. } \\
\text { In addition, there are UPTDs in } \\
13 \text { Regencies and } 1 \text { City under } \\
\text { the Regional Revenue Office of } \\
\text { the Central Kalimantan. }\end{array}$ & $\begin{array}{l}\text { It is still limited on the UPTD } \\
\text { which located in the capital of } \\
\text { province and the capital of the } \\
\text { regency. } \\
\text { There needs to add UPTDs } \\
\text { into the sub-district area due } \\
\text { to the geographical area of } \\
\text { Kalimantan which is difficult } \\
\text { to reach and limited access to } \\
\text { internet networks. }\end{array}$ & $\begin{array}{l}\text { With the geographical } \\
\text { conditions of Central } \\
\text { Kalimantan, especially } \\
\text { the target of sector } 3 \mathrm{P} \\
\text { (mining, plantation and } \\
\text { forestry) which located } \\
\text { far from the capital of } \\
\text { Province and Regency, } \\
\text { there should add the } \\
\text { UPTD into sub-district. } \\
\text { So, by the availability } \\
\text { UPTD in the sub-district } \\
\text { will make easier for } \\
\text { companies to take part in } \\
\text { Grants and Third Party } \\
\text { Donations under the } \\
\text { applicable regulations. }\end{array}$ \\
\hline Disposition & $\begin{array}{l}\text { The employees of Regional } \\
\text { Revenue Office have maximally } \\
\text { in providing services related } \\
\text { to the implementation of } \\
\text { Governor's Regulation No.16/ } \\
\text { 2018. Integrity, Totality and } \\
\text { Commitment in services have } \\
\text { carried out maximally. }\end{array}$ & $\begin{array}{l}\text { Need to increase the welfare } \\
\text { for employees who work on } \\
\text { Saturdays. }\end{array}$ & $\begin{array}{l}\text { The employees of } \\
\text { Regional revenue Office, } \\
\text { especially in the UPTD } \\
\text { who work until Saturday, } \\
\text { still keep their integrity } \\
\text { and commitment in } \\
\text { providing services, so } \\
\text { that there is an increase }\end{array}$ \\
\hline
\end{tabular}


connection from page 257

\begin{tabular}{|c|c|c|c|}
\hline Variable & The current Condition & Problem Identification & Ideal Condition \\
\hline & $\begin{array}{l}\text { Even, the Central Kalimantan } \\
\text { Provincial Government imposed } \\
5 \text { Working Days, Monday - } \\
\text { Friday and UPTD opens until } \\
\text { Saturday. } \\
\text { Especially for Monday - Friday, } \\
\text { UPTD opens At } 07.00 \text { AM - } \\
\text { 03.30 PM WIB and on Saturday, } \\
\text { UPTD open at } 07.00 \text { - } 11.00 \text { AM. }\end{array}$ & & $\begin{array}{l}\text { in local Regional } \\
\text { revenue }(P A D) \text { through } \\
\text { grants and third-party } \\
\text { donations in Central } \\
\text { Kalimantan province. } \\
\text { In addition, the welfare } \\
\text { of employees who work } \\
\text { on Saturdays still gets the } \\
\text { attention by the Central } \\
\text { Kalimantan provincial } \\
\text { government. }\end{array}$ \\
\hline $\begin{array}{l}\text { Bureaucratic } \\
\text { Structure }\end{array}$ & $\begin{array}{l}\text { There has good cooperation } \\
\text { with the Regional Revenue } \\
\text { Office with other agencies } \\
\text { related to the implementation of } \\
\text { these regulations. } \\
\text { The organizations have their } \\
\text { respective responsibilities, such } \\
\text { as Civil Service Police Unit } \\
\text { (Satpol PP), Regional Finance } \\
\text { Office and Regional Revenue } \\
\text { Office. }\end{array}$ & $\begin{array}{l}\text { The regulation is still relatively } \\
\text { new, so that not all society and } \\
\text { companies on } 3 \text { P sector do not } \\
\text { fully know and understand the } \\
\text { regulation and the organization } \\
\text { must strengthen its cooperation } \\
\text { and explain to the public about } \\
\text { the flow of payments and } \\
\text { management of transparency } \\
\text { and accountability of Grant. }\end{array}$ & $\begin{array}{l}\text { Communities in Central } \\
\text { Kalimantan province } \\
\text { especially companies on } \\
3 \text { P have fully understand } \\
\text { the management and } \\
\text { accountability of grants / } \\
\text { third-party donations. }\end{array}$ \\
\hline
\end{tabular}

Source: Regional Revenue Office Provinsi Kalimantan Tengah Year 2018

grants in accordance with the purpose of the governor regulations in Article 3 paragraph 1 No. 16/ 2018.

The steps taken by the Central Kalimantan Provincial Revenue Office as the leading sector of Governor Regulation No. 16/2018 are as follows:

1. Carry out promotion of the Central Kalimantan governor's regulation number. 16 of 2018 as well as coordination meetings with the business world, especially on sector 3 P (mining, plantations, and forestry), the people of Central Kalimantan, youth leaders, community leaders and custom leaders on July 18, 2018.

2. Coordinate with the Regional House of Representative in Central Kalimantan Provincial on the Governor Regulation No. $16 / 2018$

3. Coordinate with the Director General of Regional Law Products and the Director General of Regional Finance of the Ministry of Home Affairs of the Republic of Indonesia
4. Make a letter of the regional secretariat, c. q. Governor of Central Kalimantan to the Regents / Mayors in Central Kalimantan on grants or donations from third parties in the 3 P sector (mining, plantation, and forestry).

5. Make the cross-sector team at the provincial level to optimize the implementation of Governor Regulation No. 16/2018

In short, the process of accepting Grants or donations from third parties to the Central Kalimantan Provincial Government describes as follows:

As an effort to account for regional government and also transparency for third parties or the public, in Chapter III of the Governor's Regulation No. 16/2018 also regulated the management of grants and thirdparty donations that grants and third-party donations of cash may deposit into accounts of regional general cash through Bank Kalteng with account number 100.001.000005278-7. With this guideline, hopefully, there is one 
Figure 2.

Process of accepting Grants or donations from third parties

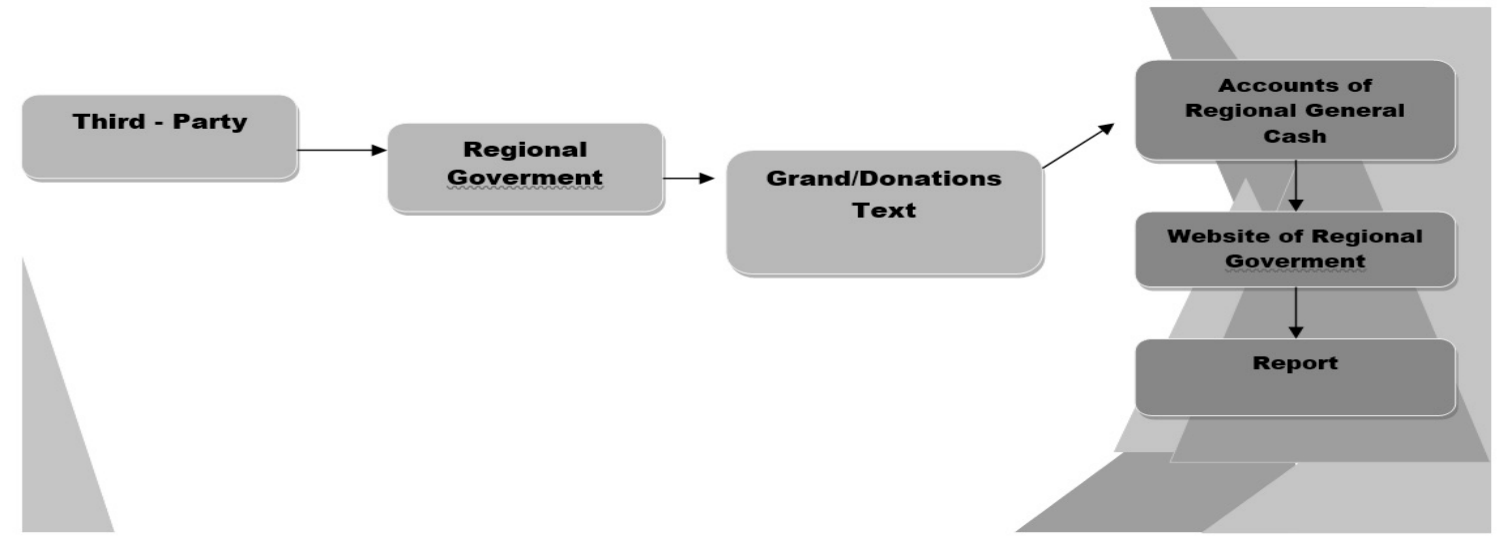

Source: Regional Revenue Office Central Kalimantan Province Year 2018

door on accepting the grants and third-party contributions, especially money. Besides, the amount of third party donations/grants was included in the APBD. So, not only the executive knew about it, but also known by the legislative, judicial and community elements in Central Kalimantan to avoid the fraud. Meanwhile, the grants or donations from third parties in the form of goods, they may deliver to regional apparatus in charge of the management of the regional property.

The principle of Grants or Third Party Donations in the Governor Regulation No. $16 / 2018$ is voluntary, sincere and not legally binding. This means that the Central Kalimantan Provincial Government does not provide certain standards / certain numbers for the private sector to donate the number of grants/ donations, in any form (goods/ money/services) are welcomed according to the ability of the donors (third-party). But, surely, the success of the governor's regulation requires cooperation from all parties aiming the regulation can implement properly to maximize the regional revenue $(P A D)$ in Central Kalimantan for more optimal development. The success of the Regulation No. 16/2018 is not only the responsibility of the local government but also to all elements, such as the private sector, the Central Kalimantan community and the Provincial Government, which are together to implement this regulation in Central Kalimantan Province.

Without the cooperation from all parties, it could be that the governor's regulation will only pass away without provided good results. In fact, the purpose of the governor's regulation is very good to invite the private sector that giving Grants and Donations can be orderly in administration. Moreover, the Regional Government is also increasingly stable in developing Central Kalimantan province along with an increase in regional revenue. The real actions from all parties that have direct interest with the potential of regional revenue (PAD) to avoid the leakage and loss of opportunities for the Central Kalimantan Regional PAD are needed. Meanwhile, the community is waiting for the extraordinary potential of wealth in Central Kalimantan to be directly proportional use for the development in the area of Central Kalimantan itself. Success or failure depends on the support and enthusiasm of the organizers or management, which are all parties who are responsible and full of sincerity in the service of the leaders and team, as well as the partners/ work teams. 


\section{Conclusion}

Based on the finding, concluded that the governor's regulation no.16 of 2018 on the accepting Regional revenue from grants and third-party donations has good goals in order to raise grant funds and especially third-party contributions from sector $3 \mathrm{P}$ (mining, plantation, and forestry) in Central Kalimantan. The purpose of the governor's regulation is to provide a legal law to guarantee third-party participation in development in Central Kalimantan, legal certainty in the management and accepting the third party grants or donations, and the creation of orderly administration, transparency and accountability for accepting grants or thirdparty donations to the government of Central Kalimantan Province. Currently, the Central Kalimantan Provincial Government through the Regional Revenue Office (Bapenda) has taken several steps, such as promoting the governor's regulations to the business sector 3 $\mathrm{P}$ (mining, plantation, and forestry), academics, traditional leaders, community leaders and the public in the Central Kalimantan Province.

The collaboration of stakeholders in Central Kalimantan Province has begun in participating to facilitate the successful implementation of the Regulation No. 16/ 2018. They have the same vision, which is to increase regional revenue $(P A D)$ in order to optimize the development and welfare of the people in Central Kalimantan Province.

\section{References}

Agustino, L. (2014). Dasar-dasar kebijakan publik. Bandung: Alfabeta.

Anggara, S. (2016). Administrasi keuangan negara. Bandung: Pustaka Setia.

Daft, R. L. (2002). Manajemen edisi kelima jilid satu. Jakarta: Erlangga.
David, O. \& Peter, P. (1997). Rewriting Government's DNA: Strategies for building a better public sector in the new democrat. Washington, DC: Democratic Leadership Council,

Indiahono, D. (2009). Kebijakan publik berbasis dynamic policy analisys. Yogyakarta: Gava Media.

Kuncoro, M. (2018). Perencanaan pembangunan daerah teori dan aplikasi. Jakarta: Gramedia Pustaka Utama.

Mardiasmo, M. (2004). Otonomi dan manajemen keuangan daerah. Yogyakarta: Andi.

Pasolong, H . (2007). Teori administrasi publik. Bandung: Alfabeta.

Reliant, R. (2017). Strategi badan narkotika nasional dalam menanggulangi darurat narkoba di kota palangka raya. Palangka Raya: Universitas Palangka Raya.

Solihin, I. (2012). Manajemen strategik. Jakarta: Erlangga.

Sobandi, B. (2005). Strategi optimalisasi pendapatan asli daerah (PAD): Kasus kota Banjarmasin. Jurnal Borneo Administrator, 1(1) 25-42.

Subkhi, A \& Jauhar, M. (2013). Pengantar teori E perilaku organisasi. Jakarta: Prestasi Pustaka.

Umar, H. (2001). Strategic management in action. Jakarta: Gramedia Pustaka Utama.

Widodo, J. (2011). Analisis kebijakan publik: Konsep dan aplikasi analisis proses kebijakan publik. Malang: Bayu Media.

Governor's Regulation of Central Kalimantan No. 16/2018 on an instruction of implementation the receiving and management of grants or donation from third-party to Provincial government of Central Kalimantan.

Law No. 12/2011 on Establishment of Law. Law No 23/2014 on Regional Government. 